\title{
Primate community of the tropical rain forests of Saracá-Taqüera National Forest, Pará, Brazil
}

\author{
Oliveira, LC. ${ }^{\text {a* }}$, Loretto, D. ${ }^{\mathrm{b}}$,Viana, LR. ${ }^{\mathrm{c}}$, Silva-Jr., JS. ${ }^{\mathrm{d}}$ and G. Fernandes, W. ${ }^{\mathrm{e}}$ \\ ${ }^{\mathrm{a}}$ Graduate Program in Biology, University of Maryland, \\ College Park, MD 20742, USA \\ 'Laboratório de Vertebrados, Departamento de Ecologia, Universidade Federal do Rio de Janeiro - UFRJ, \\ CP 68020, CEP 21941-590, Rio de Janeiro, RJ, Brazil \\ 'Laboratório de Mastozoologia e Manejo de Fauna, Departamento de Zoologia, \\ Universidade Federal de Minas Gerais - UFMG, \\ Av. Antonio Carlos, 6627, CEP 31275-000, Belo Horizonte, MG, Brazil \\ ${ }^{\text {d} S e t o r ~ d e ~ M a s t o z o o l o g i a, ~ C o o r d e n a c ̧ a ̃ o ~ d e ~ Z o o l o g i a, ~ M u s e u ~ P a r a e n s e ~ E m i ́ l i o ~ G o e l d i, ~}$ \\ CP 399, Belém CEP 66040-170, PR, Brazil

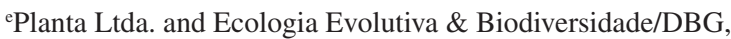 \\ Instituto de Ciências Biológicas - ICB, Universidade Federal de Minas Gerais - UFMG, \\ CP 486, CEP 30270-901, Belo Horizonte, MG, Brazil \\ *e-mail: leoecol@umd.edu
}

Received June 9, 2008 - Accepted August 21, 2008 - Distributed November 30, 2009

(With 1 figure)

\begin{abstract}
Brazil is the richest country in the world in terms of primate species and the Amazonian rain forest is one of the richest biomes containing 15 (ca. 90\%) of the Neotropical primate genera. Although considered key elements in conservation strategies, there is only anecdotal information on primates for several protected areas within the region. Here we present new data on the community composition of the primates in the Saracá-Taquiera National Forest (429,600 ha), an actively mined, bauxite rich area, in Pará, Brazil. We used information from the literature, technical reports, museum data, and interviews conducted with agents from the Brazilian Institute of the Environment and Natural Renewable Resources (Instituto Brasileiro do Meio Ambiente e dos Recursos Naturais Renováveis - IBAMA) and members of the local "Quilombo" community. In addition, from July 2003 to June 2007, we carried out 19 field trips ranging from 10 to 15 days each, amounting to a total effort of 1,230 hours and 1,420 km of censuses, resulting in 1,034 records of eight primate species (Saguinus martinsi, Saguinus midas, Saimiri sciureus, Cebus apella, Pithecia pithecia, Chiropotes sagulatus, Ateles paniscus, and Alouatta macconelli). Two other species (Cebus olivaceus and Aotus trivirgatus) were recorded only indirectly, through interviews and literature data. In all, Alouatta macconelli was the most frequently recorded species (43\% of all records); while Saguinus midas and P. pithecia were the least (ca. 0.4 and $0.6 \%$ of all records). Based on our results, we discuss group sizes as well as taxonomic problems concerning the genera Pithecia and Chiropotes, for which we registered individuals displaying phenotypic geographical variation and two different forms, respectively. Despite the deforestation inherent in bauxite mining, the Saracá-Taqüera National Forest still has a remarkable richness of primate species. Our study results place this National Forest amongst the richest reserves, in terms of primate species, in the Amazon region.
\end{abstract}

Keywords: primate community, Amazon basin, protected areas, taxonomic problems.

\section{Comunidade de primatas de uma floresta tropical úmida da Floresta Nacional do Saracá-Taquera, Pará, Brasil}

\section{Resumo}

O Brasil tem o maior número de espécies de primatas do mundo, e a Amazônia é uma das mais ricas florestas, com 15 (cerca de 90\%) dos gêneros de primatas neotropicais. Embora considerados elementos essenciais nas estratégias atuais de conservação, de modo geral há grande escassez de informação sobre os primatas das áreas protegidas na região. Apresentamos aqui novos dados sobre a composição da comunidade de primatas na Floresta Nacional SaracáTaquera (429.600 ha), Pará, uma área rica em bauxita e explorada por uma empresa mineradora nacional. Usamos informações da literatura, relatórios técnicos, dados de museus e entrevistas com agentes do IBAMA e membros da 
comunidade quilombola local. Além disso, realizamos 19 excursões de 10 a 15 dias de duração cada, no período de julho de 2003 a junho de 2007, em um esforço total de 1.230 horas e $1.420 \mathrm{~km}$ de censos, resultando em 1.034 registros de oito espécies de primatas (Saguinus martinsi, Saguinus midas, Saimiri sciureus, Cebus apella, Pithecia pithecia, Chiropotes sagulatus, Ateles paniscus e Alouatta macconelli). Outras duas espécies (Aotus trivirgatus e Cebus olivaceus) foram somente registradas de forma indireta (literatura e museus). Alouatta macconelli foi a espécie mais frequentemente registrada (43\% de todos os registros); Saguinus midas e P. pithecia foram as espécies menos frequentes (ca. 0,4 e 0,6\% dos registros). Discutimos os tamanhos de grupo registrados, bem como os problemas taxonômicos existentes, principalmente relativos aos gêneros Pithecia e Chiropotes, para os quais registramos variação geográfica e duas formas diferentes, respectivamente. Apesar do desmatamento causado pela mineração de bauxita, a Floresta Nacional Saracá-Taquera ainda possui notável riqueza de espécies de primatas. Nossos resultados colocam a área de estudo entre as mais ricas reservas em primatas na Região Amazônica.

Palavras-chave: comunidade de primatas, Bacia Amazônica, áreas de Protegidas, problemas taxonômicos.

\section{Introduction}

Brazil has the highest number of primate species in the world, with 137 recorded taxa (IUCN PSG, 2007), many of these endemic. Several of these species are listed as threatened by the IUCN (IUCN, 2007). The main threat to these species is habitat loss and fragmentation. Currently, in the national red list, 26 taxa are considered "Threatened", seven "Near Threatened", and for 16 other, there is insufficient data (Machado et al., 2005). Another threat to primate communities in Brazil is the gap in knowledge related to their geographical distribution. This lack of knowledge represents an obstacle to species conservation (Silva Júnior, 1998; Vivo, 1996). Concurrently, basic information on the biology and ecology of many species and subspecies also remains uncertain.

The Amazon biome is one of the main biomes in Latin America (Goldani et al., 2006) and it is one of richest forests in terms of primate species in the world, with 15 of the 17 Neotropical primate genera represented (Rylands et al., 2000). Currently 86 species occur in this biome, 82 of which are endemic and 18 have restricted geographic distributions. Despite this great richness and endemism, community composition spanning a wide geographic range remains unresolved. Although primates represent key elements in the conservation strategies of tropical rain forests, this important information is anecdotal for several protected areas within the region (Rylands et al., 1997).

In an attempt to bridge this gap in knowledge regarding primate diversity in protected areas of rain forests in the Amazonian region, we present here new data on the primate community composition in the Saracá-Taquiera National Forest, Pará, Brazil.

\section{Material and Methods}

\subsection{Study area}

This study was conduct in the Saracá-Taqüera National Forest, a protected area 429,600 ha in size, located in the western region of Pará state, Brazil. Fieldwork was carried out in the district of Porto de
Trombetas $\left(01^{\circ} 40^{\prime} \mathrm{S}\right.$ and $\left.56^{\circ} 00^{\prime} \mathrm{W}\right)$, a bauxite rich area, $100 \mathrm{~km}$ west of the confluence of the Trombetas and Amazonas rivers. The area is mined by Rio do Norte Mining company (Mineração Rio do Norte), which deforests some of the plateaus within the National Forest to extract bauxite. After the removal of the bauxite, areas are reforested with native plant species, based on previous botanical surveys (Oliveira et al., 2006).

The study area is located in the lowland forest domain (Ab'Saber, 1971), dominated by evergreen forest (IBGE, 1993), within which a canopied inferior layer of broad-leaf plant species and the absence of a typical understory occur. Although the mean canopy height is approximately $30 \mathrm{~m}$, some emergent species, such as the cabbage-bark tree (Andira spp. (Bonpl)) and the Brazil nut tree (Bertholletia excelsa) can reach $45 \mathrm{~m}$ in height (Brandt Meio Ambiente, 2001). We focused our ongoing study in two plateaus (Figure 1), locally known as "Almeidas" (850 ha) and "Bacaba" (200 ha).

\subsection{Field procedures and data compilation}

A preliminary list of the probable taxa occurring within the study area was compiled based on distributional maps found in the literature (Andrade, 2007; Gregorin, 1996; 2006; Hershkovitz, 1977; 1979; 1983; 1984; 1985; 1987; Hirsh et al., 1991; 2002; Kellogg and Goldman, 1944; Oliveira et al., 2004; Silva Junior, 2001; Thorington, 1985). Two technical reports: the SaracáTaquiera National Forest Management Plan (STCP, 2001) and an environmental impact assessment of the effects of the bauxite mining operation within the Forest (Brandt Meio Ambiente, 2001) were also consulted in order to gather information. We also obtained records from specimens deposited in the following mammal collections: the Zoology Museum at the University of São Paulo (Museu de Zoologia, Universidade de São Paulo - MZUSP), the Rio de Janeiro National Museum at the Rio de Janeiro Federal University (Museu Nacional do Rio de Janeiro, Universidade Federal do Rio de Janeiro - MNRJ), and the Emílio Goeldi Museum (Museu Paraense Emílio Goeldi - MPEG). Further data were provided by interviews conducted with four agents from the Brazilian Institute 


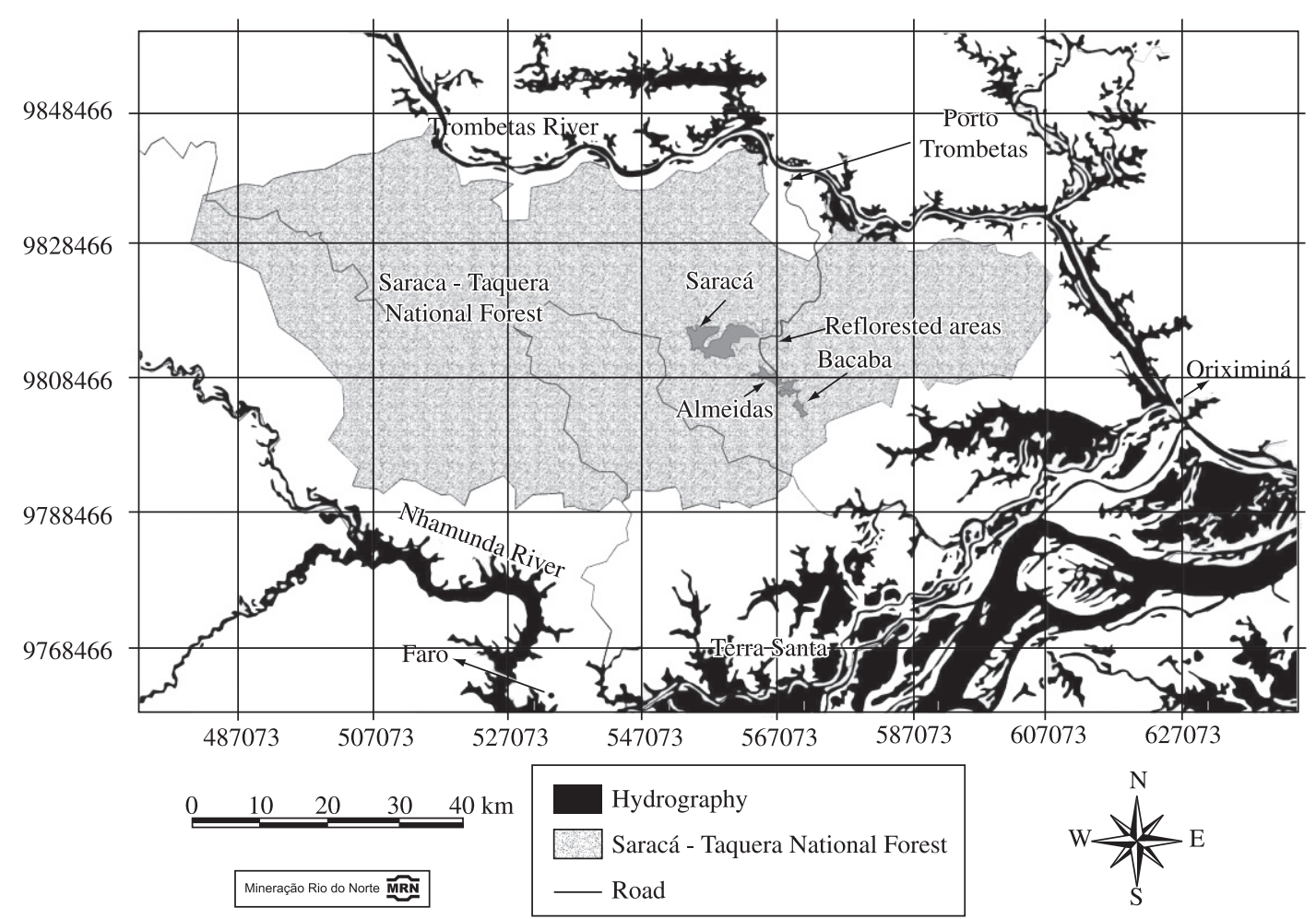

Figure 1. Map of the Saracá-Taquiera National Forest with the study areas (Almeidas and Bacaba plateaus) represented. Geographic coordinates in UTM.

of Environment and Renewable Natural Resources (IBAMA), our field assistants $(n=10)$, and members of the local "Quilombo" community, descendents of runaway slaves which took to living in remote locations and are quite knowledgeable of local wildlife. During the interviews, we presented the interviewees with illustrations of fauna from Emmons and Feer (1997) and personal photos of primate species with possible occurrence in the region and those with improbable occurrence in the region. We then asked them to identify those that they had seen in the region. For each record reported, we noted the species, the type of record (i.e. visual, vocalisation, etc.), and location and estimated date. We also questioned the interviewees on the use of primates as a source of protein in their diet; this being affirmed we requested to see any skeletal or pelage remains for species confirmation.

From July 2003 to June 2007, we carried out 19 field trips ranging from 10 to 15 days each. Two teams each composed of one researcher and one field assistant, censused the primates on the plateaus and the surrounding lowland areas. The censuses were carried out by walking at an average of $1 \mathrm{~km} / \mathrm{h}$, starting at 5:00-6:00 AM, and ending at 12:00 AM. This period of the day represents the range in which Neotropical primates are known to be the most active (NRC, 1981). We made additional opportunistic sightings between 3:00 to 6:00 PM. Primate records were obtained ad libitum (Altmann, 1974). When primate groups were located and species identified, we recorded information on their group size, type of record, and time of day. For all records we also obtained geographic coordinates with the use of Global Positioning System (GPS) units (models: E-trex and $12 \mathrm{XL}$, Garmin Inc. Olathe, Kansas) calibrated to the WGS84 datum. For comparison with other Amazonian and Atlantic forest sites, we arranged the data in a kilometric index indicating the number of primate groups sighted per $10 \mathrm{~km}$ walked (hereafter termed number of sightings).

\section{Results}

According to the literature, ten primate species (Saguinus martinsi (Thomas, 1912), Saguinus midas (Linnaeus, 1758), Aotus trivirgatus (Humboldt, 1811), Saimiri sciureus Linnaeus, 1758, Cebus apella Linnaeus, 1758, Cebus olivaceus Schomburgk, 1848, Pithecia pithecia Linnaeus, 1766, Chiropotes sagulatus Traill, 1821, Ateles paniscus Linnaeus, 1758 and Alouatta macconelli Linnaeus, 1766) have geographic distributions that encompass the study area. Of these 10 species with expected occurrence in the study area, only A. trivirgatus and $C$. olivaceus were not directly sighted by us, although they were recorded in interviews, museum collections and literature records (Table 1). In the field, with a sample effort of 1,230 hours and 1,420 km of censuses, we obtained 1,034 records of eight primate species (Table 1).

Alouatta macconnelli was the most frequently recorded species, accounting for $43 \%$ of all records, fol- 
lowed by Cebus apella with $16 \%$ and Ateles paniscus with $14 \%$. The prevalence of A. macconnelli records, in the field, was due to their potent vocalisations, resulting in a greater number of indirect records for this species. The rarest of the sighted species in the study was Saguinus midas with only four records $(0.39 \%$ of all records) during the entire study. Taking into consideration records obtained only by direct observations, $C$. apella and C. sagulatus were the most recorded species with 151 and
120 records, respectively (1.06 and 0.84 sights $/ 10 \mathrm{~km}$ respectively), followed by A. macconnelli with 117 records (0.82 sights $/ 10 \mathrm{~km})$. Group sizes varied among the species within the study, with the highest average group size observed in $C$. sagulatus with about 9 individuals while the lowest average was for $S$. midas with 2 individuals per group (Table 2)

The number of sightings in our study was greater than all "terra firme" sites surveyed by Peres (1997)

Table 1. Primates either recorded in or reported from the Saracá-Taquiera National Forest region, Pará, Brazil, based on scientific collections, published reports and fieldwork.

\begin{tabular}{|c|c|c|c|c|}
\hline \multirow{2}{*}{ Order Primates } & \multirow[t]{2}{*}{ Field work } & \multicolumn{2}{|c|}{ Literature } & \multirow[t]{2}{*}{ Scientific collection } \\
\hline & & $\begin{array}{l}\text { Scientific papers } \\
\text { and thesis }\end{array}$ & $\begin{array}{l}\text { Technical } \\
\text { Reports }\end{array}$ & \\
\hline \multicolumn{5}{|l|}{ CALLITHRICIDAE } \\
\hline Saguinus martinsi & Obs. & $1,2,15$ & & MN, MPEG \\
\hline Saguinus midas & Obs. & 1,3 & A,B & MN, MPEG, MZUSP \\
\hline \multicolumn{5}{|l|}{ AOTIDAE } \\
\hline Aotus trivirgatus & Int. & 1,4 & A & MPEG \\
\hline \multicolumn{5}{|l|}{ CEBIDAE } \\
\hline Saimiri sciureus & Obs. & $1,5,6$ & $\mathrm{~A}, \mathrm{~B}$ & MN, MPEG, MZUSP \\
\hline Cebus olivaceus* & Int. & 1,7 & & \\
\hline Cebus apella & Obs. & $1,7,15$ & A,B & MN, MPEG, MZUSP \\
\hline \multicolumn{5}{|l|}{ PITHECIIDAE } \\
\hline Pithecia pithecia & Obs. & $1,8,9,15$ & A,B & MPEG, MZUSP \\
\hline Chiroptes sagulatus** & Obs. & $1,10,15$ & A,B & MPEG, MZUSP \\
\hline \multicolumn{5}{|l|}{ ATELIDAE } \\
\hline Alouatta macconnelli** & Obs. & $1,11,12,13,15$ & $\mathrm{~A}, \mathrm{~B}$ & MN, MPEG, MZUSP \\
\hline Ateles paniscus & Obs. & $1,14,15$ & $\mathrm{~A}, \mathrm{~B}$ & MN, MPEG, MZUSP \\
\hline
\end{tabular}

Literature: 1. Hirsh et al., 2002; 2. Oliveira et al., 2004; 3. Hershkovitz, 1977; 4. Hershkovitz, 1983;

5. Hershkovitz, 1984; 6. Thorington, 1985; 7. Silva Júnior, 2001; 8. Hershkovitz, 1979; 9. Hershkovitz, 1987;

10. Hershkovitz, 1985; 11. Gregorin, 1996; 12. Gregorin, 2006; 13. Hirsch et al., 1991; 14. Kellogg and Goldman, 1944; 15. Andrade, 2007. Technical reports: A. STCP, 2001; B. Brandt Meio Ambiente, 2001.

*Species recorded by interview and observed in the Porto Trombetas Biological Reserve.

**Alouatta macconnelli $=$ Alouatta seniculus and Chiroptes sagulatus $=$ Chiroptes satanas chiropotes in Andrade (2007). Obs. = Direct observation of the species; Int. = Interview

Table 2. Number of total records, direct observation records, and group size (range and average) as well as records and direct sightings per $10 \mathrm{~km}$ of the eight species of primates recorded in the fieldwork at the Saracá-Taquiera National Forest.

\begin{tabular}{|c|c|c|c|c|c|}
\hline Order Primates & All records* & $\begin{array}{c}\text { Direct } \\
\text { observation }\end{array}$ & $\begin{array}{c}\text { Sightings per } \\
10 \mathrm{~km} \\
\end{array}$ & $\begin{array}{c}\text { Group Size } \\
\text { Range } \\
\end{array}$ & $\begin{array}{c}\text { Average } \\
\text { Group Size }\end{array}$ \\
\hline \multicolumn{6}{|l|}{ CALLITHRICIDAE } \\
\hline Saguinus martinsi & 101 & 96 & 0.68 & 1 to 20 & 3.79 \\
\hline Saguinus midas & 4 & 4 & 0.03 & 1 to 4 & 2.00 \\
\hline \multicolumn{6}{|l|}{ CEBIDAE } \\
\hline Saimiri sciureus & 22 & 22 & 0.15 & 1 to 20 & 3.75 \\
\hline Cebus apella & 167 & 151 & 1.06 & 1 to 20 & 5.38 \\
\hline \multicolumn{6}{|l|}{ PITHECIIDAE } \\
\hline Pithecia pithecia & 6 & 6 & 0.04 & 4 to 5 & 4 \\
\hline Chiropotes sagulatus & 142 & 120 & 0.84 & 1 to 36 & 9.15 \\
\hline \multicolumn{6}{|l|}{ ATELIDAE } \\
\hline Alouatta macconnelli & 448 & 117 & 0.82 & 2 to 9 & 3.56 \\
\hline Ateles paniscus & 144 & 68 & 0.48 & 1 to 18 & 3.25 \\
\hline
\end{tabular}

*All records include feces, vocalisation and direct observation. 
for the genus Alouatta, Ateles and Chiropotes although less when compared to data from Parry et al., (2007) for Alouatta and Ateles. The number of sightings for the species of the genus Saguinus, Saimiri and Pithecia were less when compared to these same studies. For the species Cebus apella our sightings were similar to those found by Peres (1997) and Parry et al., (2007) (Table 3).

Also of note were records of what appeared to be two different phenotypes of Chiropotes sagulatus, although this requires further verification. One of the forms, the most frequently recorded, follows the pattern usually described for the species (reddish-brown body with dark extremities) while the other presented much darker coloration, with almost the entire body black or dark brown. We also recorded, by direct observation, one form of the genus Pithecia with a white facial mask with yellowish cheeks, which can be an intermediary form between subspecies of this genus.

\section{Discussion}

Our study recorded 10 primate species in the SaracáTaqüera National Forest, which places the SaracáTaquiera National Forest among the richest reserves in primate species in the Amazon region (Rylands, 1985; Rylands and Bernardes, 1989). Furthermore, given its size and state of conservation, there is the potential for the discovery of more species or forms. Support for this comes from our preliminary observations of another form of the genus Chiropotes, and possibly of the genus Pithecia, although proof of this requires the collection of specimens and further morphological and genetic analysis. This richness is higher than that previously proposed $(\mathrm{N}=8)$ for the National Forest (Andrade, 2007). Different sampling effort between our study and Andrade (2007) $(1,420 \mathrm{~km}$ and $800 \mathrm{~km}$ respectively in plateau areas) and use of different methodologies (Interviews and Scientific collections) may explain this difference.

A technical report (STCP, 2001) indicated the presence of Saguinus midas niger (= Saguinus niger) and Ateles belzebuth marginatus (= Ateles marginatus) in the Saracá-Taqüera National Forest. We believe these species are unlikely to occur in the study area because their original geographic distribution does not encompass this region, being restricted to the south of the Amazon River (Hershkovitz, 1977; Hirsh et al., 2002; Martins et al., 1988).

The prevalence of A. macconnelli (in total records) within the Saracá-Taqüera National Forest primate community may be explained by the fact that the genus normally reaches high densities (Neville, 1972; Rudran, 1979; but also see Terborgh et al., 2001) has small home range sizes (4-60 ha; Defler, 2003) and a powerful vocalisation. All of these facts are considered a result of the genus's ability to use leaves as a major part of their diet.

Table 3. Sightings per $10 \mathrm{~km}$ found in Saracá-Taqüera National Forest and the range of sightings per $10 \mathrm{~km}$ from other sites in Amazon terra firme forest.

\begin{tabular}{|c|c|c|c|c|}
\hline Order Primates & $\begin{array}{c}\text { Direct } \\
\text { observation }\end{array}$ & $\begin{array}{l}\text { Sightings } \\
\text { per } 10 \mathrm{~km}\end{array}$ & $\begin{array}{l}\text { Range of sightings per } \\
10 \mathrm{~km} \text { in Amazonian } \\
\text { terra firme forest sites }\end{array}$ & $\begin{array}{l}\text { Taxa found in the } \\
\text { literature for } \\
\text { comparisons }\end{array}$ \\
\hline \multicolumn{5}{|l|}{ CALLITHRICIDAE } \\
\hline Saguinus martinsi & 96 & 0.68 & $2.1-6.3(1)$ & $\begin{array}{l}\text { Saguinus mystax, } \\
\text { Saguinus fuscicolis }\end{array}$ \\
\hline Saguinus midas & 4 & 0.03 & $0.91(4)$ & Saguinus midas \\
\hline \multicolumn{5}{|l|}{ CEBIDAE } \\
\hline Saimiri sciureus & 22 & 0.15 & $0.2-5.0(1)$ & Saimiri boliviensis \\
\hline Cebus apella & 151 & 1.06 & $0.2-3.3(1,4)$ & Cebus apella \\
\hline \multicolumn{5}{|l|}{ PITHECIIDAE } \\
\hline \multirow[t]{2}{*}{ Pithecia pithecia } & 6 & 0.04 & $0.5-2.3(1)$ & $\begin{array}{l}\text { Pithecia irrorata } \\
\text { Pithecia monachus }\end{array}$ \\
\hline & & & $0.13-0.21(4)$ & Pithecia pithecia \\
\hline Chiropotes sagulatus & 120 & 0.84 & $\begin{array}{c}0.53(2) \\
0.11-2.07(3)\end{array}$ & $\begin{array}{l}\text { Chiropotes albinasus } \\
\text { Chiropotes s. utahicki }\end{array}$ \\
\hline \multicolumn{5}{|l|}{ ATELIDAE } \\
\hline Alouatta macconnelli & 117 & 0.82 & $0.1-0.7(1)$ & Alouatta seniculus jurua \\
\hline & & & $0.13-1.2(4)$ & Alouatta macconnelli \\
\hline Ateles paniscus & 68 & 0.48 & $\begin{array}{c}0.2-0.4(1) \\
1.39(4)\end{array}$ & $\begin{array}{l}\text { Ateles paniscus chamek } \\
\text { Ateles paniscus }\end{array}$ \\
\hline
\end{tabular}

1) From Peres (1997); 2) From Peres et al. (2003); 3) From Bobadilha and Ferrari (2000); and 4) From Parry et al. (2007). 
In fact, Terborgh et al. (2001) reported howler monkeys occurring in very small islands in Venezuela at densities equivalent to a $1,000 \mathrm{ind} / \mathrm{km}^{2}$. Yet, the energetic returns from fermentation are not sufficient to allow individuals to travel great distances, therefore explaining their small home ranges, and lack of actively patrolled territories. This causes groups to overlap at times as well as use vocalisations as a more energy efficient means of avoiding conflicts (Macdonald, 2006). The number of vocalisation records for A. macconnelli increased as the deforestation of the plateau increased (personal observation), which could be a result of groups "crowding" together in response to the decrease in available habitat within the plateaus, thereby forcing groups to move into surrounding lowland areas where other groups may already have established home ranges. This "crowding effect" may also be an explanation for the difference between the sighting rates found in our study and those in the literature. In our study, the genus Ateles, Alouatta and Chiropotes presented a greater number of sightings than those presented by Peres (1997) for terra firme sites although greater values for $A$. paniscus and A. maconnelli were recorded by Parry et al., (2007). Sighting rates of between 0.2 and 0.5 groups per $10 \mathrm{~km}$ are common in surveys of Chiropotes populations, although greater values have also been recorded (see Bobadilla and Ferrari 2000). Low sighting rates for the genus Ateles, Alouatta and Chiropotes seem to be common in Amazonian terra firme sites (Peres 1997; see Bobadilla and Ferrari, 2000 for the genus Chiropotes). Thus, we believe that our greater rates are a result of the decrease in native forest area because of deforestation for mining in the plateaus, causing those species to be more easily sighted. For the genus Saguinus and Saimiri, the low sighting results were as expected. The genus Saguinus as other callithricidae are known to prefer secondary forest (Rylands, 1987 ) and are usually abundant in this habitat type (Parry et al., 2007) while Saimiri is usually abundant in varzea areas (Peres, 1997), habitat types not found in the plateaus. However, the discrepancies between co-generics cannot be attributed to systematics per se. Variation in habitat structure and sample effort may be the explanatory variables for those differences. For the same taxa, among different studies, there were large differences in sighting rates (see Peres, 1997; Parry et al., 2007 for Amazonian primates and Chiarello, 1995 for Atlantic Forest primates).

Group sizes recorded here, for A. macconnelli, (2-9) are similar to those found in another study conducted in the Saracá-Taquiera National Forest (Andrade, 2007) as well as those found in the literature (6-9 Crockett and Eisenberg, 1987), although greater values have also been recorded (more than 16 individuals Defler, 2003). The red-backed saki, Chiropotes sagulatus, the second most abundant species in the study, in terms of direct records, presented the highest group sizes with up to 36 individuals in one observed group. Our findings supported results found in other studies for this species (Ayres,
1981; Frazão, 1992; Roosmalen et al. 1981; Andrade, 2007). Given that the species presents ample home ranges (200-500 ha) and daily movements (Ayres, 1981; Roosmalen et al., 1981), the existence of many groups in the plateaus is unlikely.

The capuchin monkey, Cebus apella, was the second most abundant species in the study (total records). However, when considering only direct observation records it was the most abundant primate species. This species uses a great diversity of habitats, from deciduous woodlands to mature forests (Defler, 2003; HernandezCamacho and Cooper, 1976) and also displays wide home ranges (90-158 ha: Defler, 1982; Stevenson et al., 1992). Hence, it is to be expected that groups would be found residing in the plateaus or using the plateau as part of their home range or territory. This species' observed group sizes (1-20) were similar to those found in Andrade (2007), although lower than those found in the literature (Defler, 2003) which could represent a response by the species to the deforestation of the plateau.

Ateles paniscus is the largest species in this genus (Roosmalen and Klein, 1988), and probably due to size constraints, it requires mature primary forests, avoiding forest edges (Roosmalen, 1980). Indeed, throughout our study, as deforestation proceeded, the number of records decreased. We found group sizes ranging from one to 18 individuals, larger than groups reported by Andrade (2007) for the same region. Elsewhere, published data indicate group sizes varying from two to nine individuals (Roosmalen, 1980). We recorded smaller groups more often, which may represent smaller feeding sub-groups, as already reported in the literature (see Roosmalen and Klein, 1988).

There is a paucity of information concerning Saguinus martinsi in the literature (Oliveira et al., 2004). The species presented group sizes of 1-14 individuals (Andrade, 2007) although we recorded groups with up to 20 individuals in reforested areas (following bauxite extraction). The larger group sizes in reforested areas may be in response to the higher primary productivity in these areas and due to the species' ability to use secondary habitats, in comparison to mature forests, where competition for resources may be lower or the environment free from natural predators, usually found in the forest. Andrade (2007) reported $S$. martinsi as the most abundant species $(\mathrm{N}=72)$ in his study at Saraca-Taquera National Forest with also the highest density $\left(89 \mathrm{ind} / \mathrm{km}^{2}\right)$ while in our study $S$. martinsi was only the fourth most abundant species. This difference may be due to the areas sampled in both studies. Our study concentrated mostly in plateau areas while Andrade (2007) had a higher sampling effort in lowland forests.

With respect to $S$. sciureus, the average group size of about four individuals (range 1-20) is smaller than that reported in the literature. Defler (2003) reported that groups of $S$. sciureus range from 10-20 individuals, although Klein and Klein (1973) and Terborgh (1983) reported groups of 25-45 individuals. Our records were 
comprised mainly of single individuals or of a few individuals found together with $C$. apella.

The golden-handed tamarin (Saguinus midas) was the species least recorded in the study, first in 2004 and then again in 2007. Our records comprised lone individuals and groups consisting of four and five individuals respectively, which corroborate group sizes described in the literature where group sizes range from 3-12 individuals with an average of 5 to 6 individuals (Snowdon and Soini, 1988).

\subsection{Taxonomic problems}

There are many problems in the taxonomy of Neotropical primates, with new species being discovered, and or rearranged (Silva Júnior, 1998; Vivo, 1996), besides the many complex groups of species (superspecies) waiting to be untangled (Grelle, 2002). The most recent publications of Brazilian primate lists are incongruent (Bicca-Marques et al., 2006; CPB/IBAMA, 2005) and when compared to the international literature (Rylands et al., 2000; Wilson and Reeder, 2005) the discrepancies are much greater. Our records of species from the genus Pithecia and Chiropotes are examples of these problems. We recorded, by direct observation, only one form of the genus Pithecia with a phenotype similar to $P$. p . pithecia although it had a white facial mask with yellowish cheeks. Other taxon of this species, P. p. chrysocephala, are also thought to occur in the area (Hershkovitz, 1987). Andrade (2007) recorded 10 groups of $P$. p. chrysocephala in Saracá-Taqüera. However, none of them was recorded in plateau areas. The specimens from Amapá deposited in the MPEG are white-faced (P. p. pithecia), while the specimens from the Negro river are red-faced. The specimens from the intermediate region are white-faced with yellowish cheeks as indicated by Silva Júnior and Cerqueira (1997). The animals recorded in the study area presented this intermediate phenotype, which suggest that there may be are two sympatric taxa of $P$. pithecia in this region. We also recorded two forms of the genus Chiropotes, based mainly on different coat color. One of the forms is much darker, almost black, while the other follows the variation of the brown pattern described for $C$. sagulatus by Silva Júnior and Figueiredo (2002).

In order to elucidate these taxonomic discrepancies we recommend further systematic monitoring studies, with collection of some individuals for morphological and genetic analysis, to resolve the taxonomic doubts as to the Chiropotes and Pithecia. These actions will provide a more accurate scenario of the primate community inhabiting the rain forest of the Saracá-Taquiera National Forest.

Despite the deforestation inherent in bauxite mining, the Saracá-Taqüera National Forest still has a remarkable richness of primate species. It gives this conservation unit a unique importance as a protected area, and makes it an excellent location to carry out studies on the dynamics of primates in response to deforestation of tropical forests.

Acknowledgements - We thank the Saracá-Taqüera National Forest - Brazilian Institute of Environment and Renewable Natural Resources (IBAMA) - Porto de Trombetas - for permission to work in the area; Antonio.A. Correia (IBAMA) for his useful insights; all of the employees of the Horto Florestal, Alexandre Castilho and Mario Pantoja of the Mineração Rio do Norte (MRN) for logistical help. We also thank Rodrigo Cambará Printes, Teresa L. H. Viana, R. R. Hilário, and S. Q. C. Ferreira for field assistance. This study was funded by the Mineração Rio do Norte SA and Planta Ltda. LCO would like to thank CAPES/ Fulbright for a fellowship in support of his doctoral studies at the University of Maryland.

\section{References}

ALTMANN, J. 1974. Observational study of behaviour: sampling methods._Behaviour, vol. 49, no. 3-4, p. 227-267.

ANDRADE, PS. 2007. Estudos populacionais dos primatas em duas florestas nacionais do oeste do Pará, Brasil. Piracicaba: USP. [Tese de Doutorado].

AYRES, JM. 1981. Observações sobre a ecologia e o comportamento dos cuxiús (Chiropotes albinasus e Chiropotes satanas, Cebidae: Primates). Manaus: INPA. [Dissertação de Mestrado].

AB'SABER, NA. 1971. A organização natural das paisagens inter e subtropicais brasileiras. In Anais do III Simpósio sobre o Cerrado. São Paulo: Edgard Blücher. p.1-14.

BICCA-MARQUES, JC., SILVA, VM. and GOMES, DF. 2006. Primates. In REIS, NR., PERACCHI, AL., PEDRO, WA. and LIMA, IP. (Ed.). Mamíferos do Brasil. Paraná: UEL. p. $101-148$.

BOBADILLA, UL. and FERRARI, SF. 2000. Habitat Use by Chiropotes satanas utahicki and Syntopic Platyrrhines in Eastern Amazonia. American Journal of Primatology, vol. 50, no. 3, p. 215-224.

BRANDT MEIO AMBIENTE. 2001. Estudos de impacto ambiental Platô Almeidas-Mineração Rio do Norte - Porto de Trombetas - Oriximiná PA. Minas Gerais: [s.n.]. Technical Report.

CHIARELLO, AG. 1995. Density and habitat use of primates at an Atlantic forest reserve of south-eastern Brazil. Revista Brasileira de Biologia = Brazilian Journal of Biology, vol. 55, no. 1 , p. $105-110$

CPB/IBAMA. 2005. Lista de espécies de primatas brasileiros. Available from: <http://www.ibama.gov.br/cpb>. Access in: June 2007.

CROCKETT, CM. and EINSENBERG, JF. 1987. Howlers: variation in group size e demography. In SMUTS, BB., SEYFARTH, RM., WRANGHAM, RW. and STRUHSAKER, TT. (Ed.). Primate societies. Chicago: University of Chicago Press. p. 54-68.

DEFLER, TR. 1982. A comparison of intergroup behavior in Cebus albifrons and Cebus apella. Primates, vol. 23, no. 3, p. 385-392.

2003. Primates de Colombia. Conservation International: serie de guías de Campo 4. Bogotá. 
EMMONS, LH. and FEER, F. 1997. Neotropical rainforest mammals: a field guide. 2 ed. Chicago: University of Chicago Press. 307 p.

FRAZÃO, RR. 1992. Dieta e estratégia de forragear de Chiropotes satanas chiropotes (Cebidae: Primates) na Amazônia Central Brasileira. Manaus: INPA. [Dissertação de Mestrado]

GOLDANI, A., CARVALHO, GS. and BICCA-MARQUES, JC. 2006. Distribution patterns of Neotropical primates (Platyrrhini) based on Parsimony Analysis of Endemicity. Revistra Brasiliera de Biologia = Brazilian Journal of Biology, vol. 66, no. 1, p. 61-74.

GREGORIN, R. 1996. Variação geográfica e taxonomia das espécies brasileiras do gênero Alouatta Lacépède, 1799 (Primates, Atelidae). São Paulo: USP. [Dissertação de Mestrado]

GREGORIN, R. 2006. Taxonomia e variação geográfica das espécies do gênero Alouatta Lacépède (Primates, Atelidae) no Brasil. Revista Brasileira de Zoologia $=$ Brazilian Journal of Biology, vol. 23, no. 1, p. 64-144.

GRELLE, CEV. 2002. Is higher-taxon analysis an useful surrogate of species richness in studies of Neotropical mammal diversity? Conservation biology, vol. 108, no. 1, p. 101-106.

HERNANDEZ-CAMACHO, J. and COOPER, RW. 1976. The nonhuman primates of Colombia. In THORINGTON, RW. and HELTNE, PG. (Ed.) Neotropical primates: field studiesand conservation. Washington: National Academic of Sciences. p. $35-69$.

HERSHKOVITZ, P. 1977. Living new world monkeys (Platyrrhini). vol. 1. Chicago: University of Chicago Press. $1117 \mathrm{p}$

1979. The species of sakis, genus Pithecia (Cebidae, Primates), with notes on sexual dichromatism. Folia Primatologica, vol. 31, no. 1-2, p. 1-22.

1983. Two new species of night monkeys, genus Aotus (Cebidae, Platyrrhini): a preliminary report on Aotus taxonomy. American Journal of Primatology, vol. 4, no. 3, p. 209-243.

1984. Taxonomy of the squirrel monkey genus Saimiri (Cebidae, Platyrrhini): a preliminary report with description of a hitherto unnamed form. American Journal of Primatology, vol. 7 , no. 3, p. 155-210.

1985. A preliminary taxonomic review of the South American bearded saki monkeys genus Chiropotes (Cebidae, Platyrrhini), with description of a new subspecies. Fieldiana Zoology, no. 27, p. 1-45.

1987. The taxonomy of South American sakis, genus Pithecia (Cebidae, Platyrrhini): A preliminary report and critical review with the description of a new species and a new subspecies. American Journal of Primatology, vol. 12, no. 4, p. $386-468$.

HIRSCH, A., LANDAU, EC., TEDESCHI, ACM. and MENEGHETI, JO. 1991. Estudo comparativo das espécies do gênero Alouatta Lacépède, 1799 (Platyrrhini, Atelidae) e sua distribuição geográfica na América do Sul. In RYLANDS, AB. and BERNARDES, AT. (Ed.). A Primatologia no Brasil 3. Belo Horizonte: Fundação Biodiversitas. p. 239-262.

HIRSCH, A., DIAS, LG., MARTINS, LO., CAMPOS, RF., LANDAU, EC. and RESENDE, NAT. 2002. BDGEOPRIM
- Database of Georreferenced Occurrence Localities of Neotropical Primates. Belo Horizonte: UFMG. Available from: $<$ www.icb.ufmg.br/ primatas/home_bdgeoprim.htm>. Access in: June 2007.

Instituto Brasileiro de Geografia e Estatística - IBGE. 1993. Mapa de vegetação do Brasil. Rio de Janeiro: IBGE. 1 map: $110 \times 92 \mathrm{~cm}$. Scale 1:5,000,000. International Union for The Conservation of Nature and Natural Resources -

IUCN. 2003. IUCN Red list of threatened species. Gland: IUCN. Available from: $<\mathrm{http}: / / \mathrm{ww}$.iucnredlist.org $>$.

INTERNATIONAL UNION FOR THE CONSERVATION OF NATURE AND NATURAL RESOURCES, PRIMATE SPECIALIST GROUP - IUCN, PSG. 2007. Global primate diversity, Brazil. Availble from: <http://www.primate-sg.org/ diversity.htm>. Access in: June 2007.

KELLOGG, R. and GOLDMAN EA. 1944. Review of the spider monkeys. Proceedings of the United States National Museum, vol. 96, p. 1-45

KLEIN, LL. and KLEIN DL. 1973. Observations on two types of Neotropical primate intertaxa associations. American Journal of Physical Anthropology, vol. 38, p. 649-653.

MACDONALD, DW. 2006. The encyclopedia of mammals. Oxford: Univerisity Press. 936 p.

MACHADO, ABM., MARTINS, CS. and DRUMMOND, GM. 2005. Lista da fauna brasileira ameaçada de extinção: incluindo as espécies quase ameaçadas e deficientes em dados. Belo Horizonte: Fundação Biodiversitas. 160 p.

MARTINS, ES., AYRES, JM. and VALLE, MBR. 1988. On the status of Ateles belzebuth marginatus with notes on other primates of the Iriri River Basin. Primate Conservation, vol. 9, p. $87-90$.

NEVILLE, MK. 1972. The population structure of red howler monkeys (Alouatta seniculus) in Trinnidad and Venezuela. Folia Primatologica, vol. 17, no. 1-2, p. 56-86.

National Research Council - NRC. 1981. Techniques for the study of primate population ecology. Washington: National Academy Press. 244 p.

OLIVEIRA, LC., MENDEL, SM., SILVA JÚNIOR, JS. and FERNANDEZ, GW. 2004. New records of Martins' bareface tamarin, Saguinus martinsi (Primates, callithrichidae). Neotropical Primates, vol. 12, no. 1, p. 9-12.

OLIVEIRA, LC., MENDEL, SM., LORETTO DM., SILVA JÚNIOR, JS. and FERNANDEZ, GW. 2006. Edentata fauna of the Saracá-Taqüera National Forest. Edentata, vol. 7, May, p. 3-7.

PARRY, L., BARLOW, J. and PERES, CA. 2007. Largevertebrate assemblages of primary and secondary forests in the Brazilian Amazon. Journal of Tropical Ecology, vol. 23, no. 6, p. $653-662$

PERES, CA. 1997. Primate community structure at twenty western Amazonian flooded and unflooded forests. Journal of Tropical Ecology, vol. 13, no. 3, p. 381-405.

PERES, CA., BARLOW, J. and HAUGAASEN, T. 2003. Vertebrate responses to suface wildfires in central Amazonian forest. Oryx, vol. 37, no. 1, p. 97-109.

ROOSMALEN, MGM. 1980. Habitat preference, diet, feeding strategy and social organization of the black spider 
monkey (Ateles paniscus paniscus) in Surinam. Wageningen: Agricultural University of Wageningen. [Tese de Doutorado].

ROOSMALEN, MGM., MITTERMEIER, RA. and MILTON, K. 1981. The Bearded Sakis, Genus Chiropotes. In COIMBRAFILHO, AF. and MITTERMEIER, RA. (Ed.). Ecology and behavior of neotropical primates. vol. 1. Rio de Janeiro: Academia Brasileira de Ciências. p. 419-441.

ROOSMALEN, MGM. and KLEIN, LL. 1988. The spider monkeys, genus Ateles. In MITTERMEIER, RA., RYLANDS, AB., COIMBRA-FILHO, AF. and FONSECA, GAB. (Ed.). Ecology and behavior of neotropical primates. vol. 2 . Washington: World Wildlife Fund. p. 455-537.

RUDRAN, R. 1979. The demography and social mobility of red howler (Alouatta seniculus) population in Venezuela. In EISENBERG, JF. (Ed.). Vertebrate ecology in northern neotropics. Washington: Smithsonian Institution Press. p. 107-126.

RYLANDS, AB. 1985. Conservation areas protecting primates in Brazilian Amazonia. Primate Conservation, vol. 5, p. 24-27.

1987. Primate communities in Amazonian forests: their habitats and food resources. Experientia, vol. 43, no. 3, p. 267-279.

RYLANDS, AB. and BERNARDES, AT. 1989. Two priority regions for primate conservation in the brazilian amazon. Primate Conservation, vol. 10, p. 56-62.

RYLANDS, AB., MITTERMEIER, RA. and RODRIGUESLUNA, H. 1997. Conservation of neotropical primates: threatened species and an analysis of primate diversity by country and region. Folia Primatologica, vol. 68, no. 3-5, p. $134-160$.

RYLANDS, AB., SCHNEIDER, H., MITTERMEIER, RA., GROVES, CP. and RODRIGUES-LUNA, H. 2000. An assessment of the diversity of New World primates. Neotropical Primates, vol. 8, no. 2, p. 61-93.

SILVA JÚNIOR, JS. and CERQUEIRA, R. 1997. Variação geográfica de Pithecia pithecia Linnaeus, 1766 (Primates, Cebidae). In Anals of the VIII Congresso Brasileiro de Primatologia e V Reunião Latino-Americana de Primatologia. João Pessoa. p. 65.

SILVA JÚNIOR, JS. 1998. Problemas de amostragem no desenvolvimento da sistemática e biogeografia de primatas neotropicais. Neotropical Primates, vol. 6, no. 1, p. 21-22.
2001. Especiação nos macacos-prego e caiararas, gênero Cebus Erxleben, 1777 (Primates, Cebidae). Rio de Janeiro: UFRJ. [Tese de doutorado].

SILVA JÚNIOR, JS. and FIGUEREDO, WMB. 2002. Revisão sistemática dos cuxiús, gênero Chiropotes Lesson, 1840 (Primates, Pitheciidae). In Livro de Resumos do XI Congresso Brasileiro de Primatologia. Belém: UFPa. p. 21.

SNOWDON, CT. and SOINI, p. 1988. The tamarins genus Saguinus In MITTERMEIER, R., RYLANDS, A., COIMBRAFILHO, A. and FONSECA, GAB. (Ed.). Ecology and Behavior of Neotropical Primates. Washington: World Wildlife Found. p. 223-298.

STCP Engenharia, Consultoria e Gerenciamento. 2001. Plano de manejo da floresta nacional de Saracá-Taqüera, Estado do Pará, Brasil. Curitiba: [s.n.]. Technical report.

STEVENSON, DP., QUIÑONES MC. and AHUMADA, JA. 2003. Relación entre la abundancia de frutos y las estrategias alimenticias de cuatro especies de Primates en La Macarena, Colombia. Unpublished manuscript, report to Banco de La República. In DEFLER, RT. (Ed.). Primates de Colombia. Bogota: Conservación Internacional Colombia.

TERBORGH, J. 1983. Five New World Primates: a study in comparative ecology. Princeton: Princeton University Press. $260 \mathrm{p}$.

TERBORGH, J., LOPEZ, L., NUÑEZ, P., RAO, M., SHAHABUDDIN, G., ORIHUELA, G., RIVEROS, M., ASCANIO, R., ADLER, GH., LAMBERT, T D. and BALBAS, L. 2001. Ecological meltdown in predator-free forest fragments. Science, vol. 294, November, p. 1923-1926.

THORINGTON, R. 1985. The taxonomy and distribution of squirrel monkeys (Saimiri). In ROSENBLUM, LA. and COE, CL. (Ed.). Handbook of squirrel monkey research. New York: Plenum Press. p. 1-33.

VIVO, M. 1996. How many species of mammals are there in Brazil? In BICUDO, CE. and MENEZES, NA. (Ed.). Biodiversity in Brazil: a first approach. Proceedings of the workshop "methods for the assessment of biodiversity in plants and animals". Campos do Jordão, São Paulo. p. 313-321.

WILSON, DE. and REEDER, DA. 2005. Mammal species of the world: a taxonomic and geographic reference. Baltimore: Johns Hopkins University Press. 2142 p. 